УДК [502.13:005]:637.1/.3 (477)

[0000-0002-4892-2931] Н. В. Загоруйко, канд. біол. наук, доцент, e-mail: nelli.zagorujko@ukr.net

[0000-0001-8975-851Х] Л. Б. Ящук, канд. хім. наук, доцент, e-mail: 1_yashchuk@ukr.net

[0000-0003-4531-1171] Н. І. Свояк, канд. біол. наук, доиент, e-mail: svojaknata@ukr.net

Черкаський державний технологічний університет

б-р Шевченка, 460, м. Черкаси, 18006, Україна ${ }^{[0000-0001-8067-8740]}$ I. С. Конопацька

e-mail: innakonopatcka@gmail.com

Черкаський науково-дослідний експертно-криміналістичний центр МВС України вул. Пастерівська, 104, м. Черкаси, Україна

\title{
ЗАБЕЗПЕЧЕННЯ ЕКОЛОГІЧНОЇ БЕЗПЕКИ ШЛЯХОМ ТЕХНІЧНОГО ПЕРЕОСНАЩЕННЯ ПІДПРИЄМСТВ ВІТЧИЗНЯНОЇ МОЛОКОПЕРЕРОБНОЇ ГАЛУЗІ
}

В Україні виробництво молочної продукиії часто здійснюється на застарілому обладнанні, через щцо екологічний тиск підприємств галузі на довкілля, особливо на водні ресурси, є значним. На прикладі Золотоніського маслоробного комбінату розглянуто можливості поліпшення екологічної складової виробництва молокопродуктів та проблеми, що виникають при технічному переоснащенні основних фондів вітчизняних підприємств. Золотоніський маслоробний комбінат з 2000-х рр. був головним забруднювачем річок Суха Згар та Золотоношка в Черкаській області за рахунок скидів значного обсягу недоочищених стічних вод. У період 20152017 рр. значні капіталовкладення в переоснащення локальних очисних споруд підприємства, встановлення безвідходних технологічних ліній дало можливість привести стан стічних вод підприємства до нормативних показників і поліпшити ситуачію із забрудненням малих річок. Водночас через значні фінансові витрати та погіршення ситуачії на ринках збуту для власників підприємства існують реальні загрози зниження конкурентоспроможності продукцї̈ та банкрутства.

Ключові слова: стічні води, якість поверхневих вод, стандарт, торгова марка, екологічні нормативи, безвідходні технології.

Вступ. Вода належить до найцінніших національних багатств України. Вона відіграє важливу роль у житті суспільства, розвитку економіки країни, покращенні стану навколишнього природного середовища. Ї̈̈ значення як природничого компонента, як елемента екосистеми важко переоцінити. За запасами доступних до використання водних ресурсів Україна належить до малозабезпечених країн. На сьогодні в Україні за ступенем забруднення води, екологічним станом практично немає жодної поверхневої водойми, яку можна віднести до водойм першої категорії з чистою питною водою. Внаслідок проведення недосконалої водної меліорації, високої розораності земель і недостатньої лісистості водозборів, розорювання прибережних захисних смуг і заплав, випрямлення русел річок спостерігається нерівномірність (розрегульованість) їх стоку, прогресуюче обміління, замулювання, забруднення і навіть зникнення. Малі річки один із важливих компонентів природного середовища, вони мають велике значення у житті та господарській діяльності людей. Їхні водні ресурси є складовою частиною загальних водних ресурсів і часто бувають основним, а інколи і єдиним джерелом місцевого водозабезпечення, що визначає розвиток та розміщення місцевих водокористувачів. Цій екологічній проблемі присвячено багато наукових досліджень, зокрема роботи О. В. Романенко, В. Д. Романенка, В. М. Жукінського, А. В. Гриценка, О. П. Оксіюк, Г. А. Верниченко, О. Г. Васенка, С. В. Багоцького, А. В. Качинського, О. Г. Наконечного [1-3].

Виробництво харчових продуктів супроводжується утворенням рідких, газоподіб- 
них і твердих відходів, що забруднюють гідросферу, атмосферу та грунти. Однак основною екологічною проблемою харчових виробництв $\epsilon$ забруднення води. Усі підприємства потребують великої кількості води, що використовується безпосередньо в технології основного продукту (пивоварна, спиртова, цукрова, маслоробна галузі), для миття обладнання та інших цілей. Більшість цієї води у вигляді забруднених стоків виводиться із процесу та надходить у навколишнє середовище (малі річки і водотоки). На сучасному етапі розвитку економіки України зростає роль процесів екологізації виробництва, реалізація яких дасть можливість розв'язувати конкретні еколого-економічні проблеми на рівні підприємства. Проблемами екологічного менеджменту займалися закордонні та вітчизняні вчені К. Ріхтер, А. Ендрес, Н. Пахомова, О. М. Теліженко, В. В. Сабадаж, О. Л. Михайлюк, В.Ф. Семенова, Т. П. Галушкіна, О. І. Барановський, В. І. Мунтіян та ін. [4-6].

Мета та задачі дослідження. Метою роботи $є$ оцінювання ефективності системи екологічного менеджменту на ТДВ «Золотоніський маслоробний комбінат» у забезпеченні екологічної безпеки водних ресурсів як модельного об'єкта вітчизняних підприємств молочної галузі.

Для досягнення поставленої мети необхідно вирішити такі задачі:

- оцінити відповідність якості очищення стічних вод встановленим нормативам скиду промислових стоків у водні об'єкти до 2015 р. на підприємстві як основному забруднювачі малих річок Суха Згар і Золотоношка;

- дослідити заходи екологічного менеджменту, впроваджені в технологічний процес виробництва продукції та процес очищення стічних вод підприємства;

- дослідити якість очищення стічних вод після впровадження заходів екологічного менеджменту на цьому підприємстві;

- оцінити відповідність якості очищення стічних вод встановленим нормативам скиду промислових стоків у водні об'єкти.

Виклад основного матеріалу. Підприємства харчової галузі справляють значний негативний вплив на природні екосистеми. Нині переважна більшість вітчизняних харчових підприємств перебуває у приватній власності. Під час приватизації нове керівництво отримало у спадок застарілі технології та спрацьовані основні фонди. Економічна скру- та, втрачені ринки збуту продукції поступово призвели до того, що на сьогодні в Україні на підприємствах харчової галузі майже відсутні ефективні очисні споруди, а діючий штрафний механізм екологічної безпеки є малоефективним і не стимулює підприємства до модернізації та переоснащення виробництва сучасними технологіями очищення стічних вод.

Стічні води молокопереробних підприємств характеризуються значним вмістом легкорозчинних органічних речовин, які, потрапляючи до природних водойм, викликають в них несприятливі зміни [7]. Наприклад, при середніх питомих витратах води $5 \mathrm{~m}^{3}$ на тонну молока, залежно від потужності підприємства, за добу утворюється близько $500 \mathrm{~m}^{3}$ стічних вод [8-9]. Крім стоків, що утворюються в результаті технологічних процесів, в каналізацію скидаються і господарсько-побутові стічні води цих підприємств.

На сучасних молочних підприємствах Європи типове забруднення стічних вод за біологічним споживанням кисню (БСК) становить 0,5-2,5 кг на $1 \mathrm{t}$ спожитого молока, за показником хімічного споживання кисню (ХCК) - близько 1,5 БСК (але ХСК може сягати $\left.8 \mathrm{\kappa} / \mathrm{m}^{3}\right)$, за завислими речовинами -100 1000 мг/л [10]. На українських молокопереробних підприємствах стічні води містять ХСК 1000-5000 $\mathrm{M \Gamma O}_{2} /$ л, БСК - 700$3700 \mathrm{MгO}_{2} /$ л, показник кислотності $\mathrm{pH}$ становить 3,6-10,4, вміст завислих речовин коливається в межах 1200-2900 мг/л [8-9]. Концентрація забруднень значною мірою залежить від виду продукції, технічного рівня виробництва, технології миття та дезінфекції обладнання і робочих місць, а також від екологічного менеджменту на підприємстві [11]. Забрудненість зростає в декілька разів, якщо технологічне устаткування на підприємстві не дає можливості утилізувати відходи переробки молока, в першу чергу сироватку. Застарілість обладнання та технологій на очисних спорудах українських підприємств молочної промисловості призводить до скидання недоочищених вод в каналізацію або безпосередньо у водойми. За ступенем забруднення стоки молокозаводів, як правило, не відповідають вимогам, які регламентують прийом та вміст зворотних вод, скинутих у каналізаційну мережу міст. Нерівномірність обсягів стічних вод, що направляються на очисні споруди, та ix надзвичайна забрудненість органічними рештками обумовлюють переобтяженість та незадовільну роботу останніх. 
Переробкою молока в Черкаській області займаються декілька потужних підприємств: ПрАТ «Звенигородський сироробний комбінат» (ТМ «Звенигора»), ТДВ «Золотоніський маслопереробний комбінат» (ТМ «Златокрай»), Канівська філія ТОВ «Клуб сиру» (ТМ «Клуб сиру»), ПрАТ «Юрія» (ТМ «Волошкове поле»), ПП «Імперіал-Плюс» (ТМ «Сладосвіт», «Молочний хутір») та ін. [12].

Таким чином, наявність значної кількості потужних молокопереробних підприємств потребує детального аналізу загроз від їх діяльності для місцевих водних екосистем та можливостей екологічного менеджменту на підприємствах для забезпечення екологічної безпеки.

На річці Золотоношка, в яку впадає річка Суха Згар, склалася складна водогосподарсько-екологічна ситуація, що неодноразово призводило до загибелі риби. Впадаючи в Кременчуцьке водосховище, Золотоношка впливає на якість питної води у містах, що розташовані на Дніпрі нижче за течією. Тому оцінювання якості стічних вод, що потрапляють до цих річок, і чинників формування їх гідрохімічного складу є досить актуальним.

Матеріали та методи дослідження. 3 метою дослідження якості очищення стічних вод на ТДВ «Золотоніський маслоробний комбінат» та їх відповідності встановленим нормативам скиду промислових стоків у водні об'єкти забір зворотних вод проводився на двох пунктах контролю якості води об'єкта дослідження. Пункт № 1 розміщується на вході технологічної схеми очищення стічних вод (СВ) (місце скиду до очисних споруд), пункт № 2 знаходиться у місці виходу очищених зворотних вод 3 очисних споруд. Аналіз фізико-хімічних властивостей стічних вод проводили за показниками БСК, ХСК, вмістом розчиненого кисню, вмістом сухого залишку, вмістом сульфат-, хлорид- та нітритйонів.

Методика розрахунку сухого залишку (розчинених речовин) полягала у фільтрації проби $\mathrm{H}_{2} \mathrm{O}$, яка надалі випарювалася. Залишок висушували протягом трьох годин при температурі $105^{\circ} \mathrm{C}$ і потім зважували. Концентрація розчиненого кисню у воді визначалася за методикою Вінклера.

Метод визначення сульфат-іонів базувався на вимірюванні світлопоглинання у напрямку падаючого променя суспензією $\mathrm{BaSO}_{4}$, яка стабілізувалася сумішшю $\mathrm{C}_{2} \mathrm{H}_{6} \mathrm{O}_{2}$ ${ }_{3} \mathrm{C}_{2} \mathrm{H}_{5} \mathrm{OH}$ у співвідношенні $1: 1$. Концентрацію хлорид-іонів встановлювали за методикою Mopa.

Результати досліджень. Золотоніський маслоробний комбінат протягом багатьох років був одним із головних джерел забруднення місцевих гідроресурсів, скидаючи недоочищені стічні води у малі річки Суха Згар та Золотоношка. Стічні води ЗМК характеризувалися порушенням нормативів за сімома показниками, зокрема: за БСК, ХСК, вмістом продуктів нафтопереробки, сульфат- та хлоридйонами, значенням кислотності та концентрації мінеральних речовин (таблиця 1) [12-13].

Таблиця 1 - Хімічні показники стічних вод Золотоніського маслоробного комбінату y 2010 p.

\begin{tabular}{|l|c|c|c|}
\hline $\begin{array}{c}\text { Показники, } \\
\text { що досліджувались }\end{array}$ & $\begin{array}{c}\text { Показники ГДС, } \\
\text { мг/дм }\end{array}$ & $\begin{array}{c}\text { Показник Золотоніського } \\
\text { маслоробного комбінату, } \\
\text { мг/дм }\end{array}$ & $\begin{array}{c}\text { Перевищення } \\
\text { ГДС }\end{array}$ \\
\hline Завислі речовини & 275 & 260 & + \\
\hline БСК & 260 & 270 & + \\
\hline ХСК & 450 & 490 & + \\
\hline СПАР & 4 & 0,11 & + \\
\hline Сульфати & 70 & 112,07 & + \\
\hline Мінералізація & 960 & 961,5 & + \\
\hline Нафтопродукти & 0,6 & 0,825 & + \\
\hline Нітрити & 10 & 7,70 & + \\
\hline Фосфати & 10 & 2,51 & + \\
\hline Хлориди & 300 & 305,72 & \\
\hline рН & $6,5-8,5$ & 8,52 & \\
\hline
\end{tabular}


У 2006 р. ЗМК увійшов до складу великого холдингу «Молочний альянс України». У складі холдингу Золотоніський комбінат перепрофілювали на виробництво твердих сирів експортного рівня якості ТДВ «Золотоніський маслопереробний комбінат». ТМ «Златокрай» $є$ першим вітчизняним підприємством, яке почало поставляти свою продукцію на європейський ринок. Водночас саме виробництво казеїну та твердих сирів характеризується високими показниками ХСК та БСК і становить найбільшу загрозу для водних екосистем.

Серед пріоритетних цілей, задекларованих власниками холдингу, є безпека навколишнього природного середовища [14]. Усі найбільші підприємства компанії пройшли сертифікацію на відповідність виробництва міжнародним стандартам ISO 9000 (управління та контроль якості) та ISO 22000 (безпека харчової продукції). Керівництво холдингу стежить за оновленням технологічних процесів та обладнання на своїх підприємствах, а також за впровадженням інноваційних технологій. За останні сім років було освоєно понад 525 млн грн. капітальних інвестицій. Серед модернізованих підприємств є й ЗМК. У 2018 р. підприємство отримало сертифікат FSSC 22000:2015 стосовно дотримання вимог системи безпечності харчових продуктів. Стандарт FSSC 22000:2015 розроблений за принципом сумісності зі стандартами ISO 9001, ISO 14001, OHSAS 18001, SA8000, ISO 22005 та ISO 22000. Сертифікат враховує не лише якість продукції, а й якість сировини, відповідні вимоги до зберігання, пакування, перевезення продукції, умови праці на підприємстві, контроль за безпекою на виробництві, дотримання екологічних норм.

За останні три роки власниками холдингу було здійснено багатомільйонні вкладення для вирішення екологічних проблем окремих підприємств, що входять до складу компанії, а саме: у будівництво власних нових очисних споруд на ПАТ «Баштанський сирзавод» та ПАТ «Золотоніський маслоробний комбінат»; у реконструкцію наявних споруд для АТ «Пирятинський сирзавод»; у впровадження на підприємствах нанофільтраційного обладнання, завдяки якому зворотні води більше не міститимуть сироватку. Ці інвестиції спрямовані на вирішення головних проблем молокопереробних підприємств та реалізацію сучасного водного менеджменту.
Виробництво твердих сирів відзначається зміною складу забруднюючих речовин у стічних водах. Особливістю відпрацьованих технологічних вод при отриманні сирної продукції є їх висока концентрація, через що їх поділяють на: меляса);

- висококонцентровані (сироватка та

- низькоконцентровані (утворюються під час санітарної обробки мийними засобами тари, технологічних ліній устаткування та підлоги цехів від залишків молочної сировини).

Обидві групи формують загальний стік, який потрапляе на споруди біологічного очищення підприємства.

У 2010-2013 рр. відпрацьовані води зовсім не відповідали екологічним нормативам. Головним джерелом їх понаднормового забруднення був злив у каналізаційну систему підприємства мийних вод після санітарної обробки обладнання та приміщення. На сьогодні на комбінаті встановлено сучасні технологічні лінії по виробництву продукції, які $\epsilon$ безвідходними. Переоснащення потребувало значних інвестицій. Реконструкція і нове будівництво окремих ділянок очисних споруд ЗМК на першому етапі модернізації коштувало новим власникам 5 млн грн. капіталовкладень. Після введення в дію у 2012-2014 pр. очисні споруди мали продуктивність $1000 \mathrm{~m}^{3} /$ добу і значну ефективність очищення стічних вод. Водночас, за результатами контрольних перевірок відповідності стічних вод підприємства екологічним нормативам, спостерігалися непостійні порушення ГДК речовин по фосфатах, ХСК. Результатом технологічного переоснащення другої та третьої ділянок очисних споруд $є$ приведення показника ХСК у зворотних водах до норми, в межах $390-420 \mathrm{M \Gamma} / \mathrm{M}^{3}$.

За роки діяльності маслоробного комбінату у складі великого холдингу на його технічну модернізацію було витрачено понад 27 млн дол. Необхідність дотримання сучасних вимог до безпеки харчової продукції, відповідності вітчизняної молокопереробної продукції європейським та світовим стандартам, конкуренція з іншими виробниками привели до повної заміни виробничих ліній на найновіші технології, наприклад, відкриття сучасного цеху з виробництва якісної сироватки. На сьогодні хімічний склад стічних вод, що підприємство скидає в каналізаційну ме- 
режу міста і які потрапляють до комунальних очисних споруд, приведено у відповідність до екологічних нормативів, діючих у країні.

Очищення стічних вод на підприємстві здійснюється поетапно.

Механічне очищення: відпрацьована технологічна та технічна вода за допомогою локальної каналізаційної насосної станції потрапляє до приймальної камери відстійникафлотатора, проходячи через систему решіток для вилучення твердих решток значних розмірів. У відстійнику-флотаторі $(\mathrm{d}=7,2 \mathrm{~m})$ за рахунок безперервного перемішування завислі речовини і жири поступово осідають.

Біологічне очищення: 3 відстійникафлотатора зворотні води потрапляють до аеротенків (d=10 м), в яких за допомогою насосів струменевої аерації відбувається обертовий рух мулової суміші всередині аеротенка. Завдяки цьому водний муловий розчин 3 нижньої частини аеротенків піднімається у їх верхні шари 3 безперервною аерацією робочого розчину атмосферним повітрям.

Надлишок активного мулу повертається у відстійники-флотатори для додаткової біологічної коагуляції забруднювальних частинок. Флотошлами i осади із відстійниківфлотаторів зневоднюють центрифугами.

Кінцеві продукти системи очищення підлягають герметичному пакуванню в контейнери і надалі вивозяться на полігон. Попередньо очищені виробничі СВ спрямовують до комунальних очисних споруд міста.

Результати очищення зворотних вод на локальних очисних спорудах ЗМК порівняно із затвердженими ГДС зображено на рисунку 1.

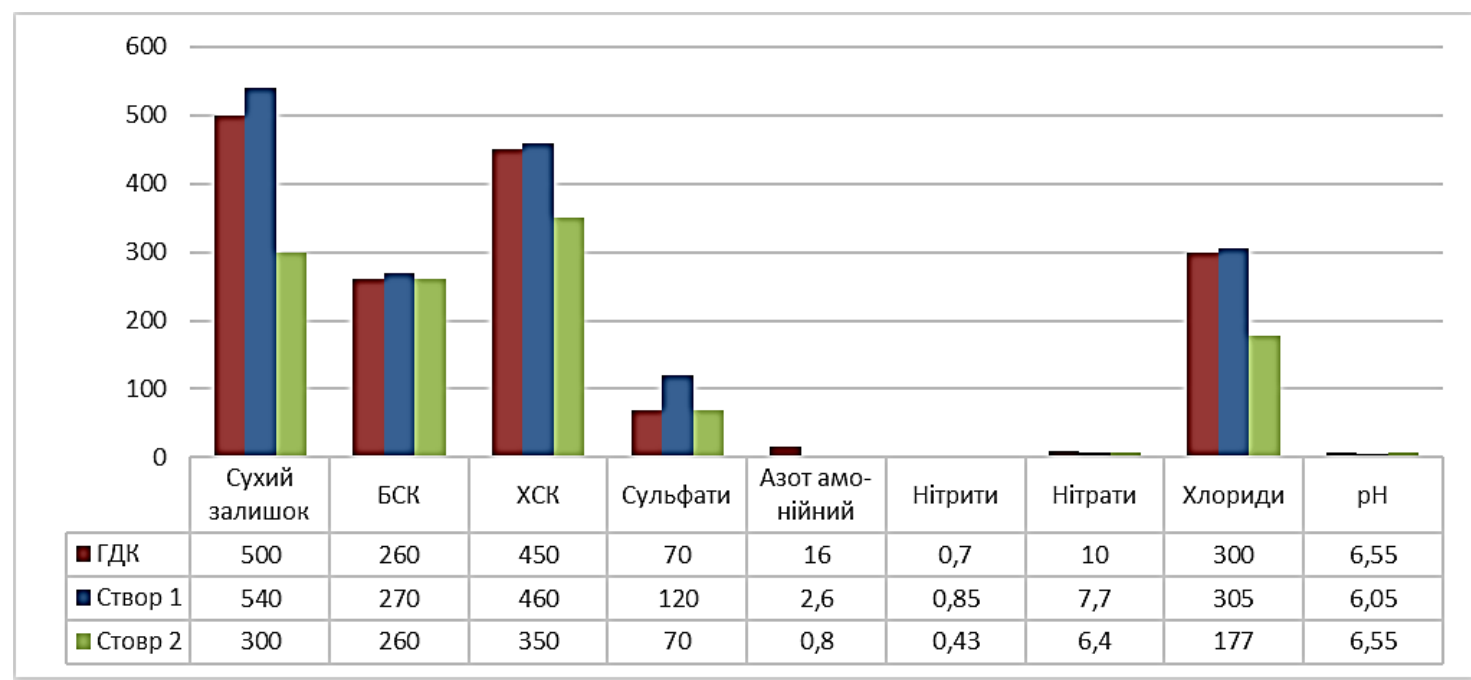

Рисунок 1 - Відповідність складу стічних вод ТДВ ЗМК екологічним нормативам після реконструкції локальних очисних споруд

Обговорення результатів. У пробах вхідної води, що потрапляють на очисні споруди ТДВ ЗМК, визначено шість показників, що мають вищі концентрації порівняно з нормативами, а вода, що скидається в міську каналізаційну систему, відповідає всім екологічним вимогам до зворотних вод. Результати лабораторних досліджень про ефективність роботи модернізованих локальних очисних споруд ЗМК наведено в таблиці 2.

Концентрація показників стічних вод після очищення на підприємстві відповідає затвердженим обсягам речовин в ГДС. Результати щорічних досліджень хімічних та мікробіологічних показників річок Суха Згар та Золотоношка свідчать про значне покра- щення річкової води за санітарно-хімічними та мікробіологічними показниками [15].

В останні роки український бізнес, 3 огляду на міжнародні тенденції, все більше демонструє зацікавленість у природоохоронних проектах, зокрема й у вирішенні проблеми зменшення негативного тиску виробничих процесів на довкілля. Дійсна екологічна відповідальність власників приватних підприємств пов'язана із мінімізацією негативного екологічного впливу свого бізнесу в тих напрямах, де цей вплив $€$ найбільш загрозливим. Крім того, запровадження екологічного менеджменту дає можливість не тільки поєднувати економічні та екологічні цілі, а ще й отримувати від цього прибуток внаслідок зменшення 
розмірів штрафних санкцій за забруднення довкілля.

Водночас існує суттєва відмінність вітчизняного бізнесу від європейського досвіду екологічної відповідальності місцевих компаній. В Європі існує практика деталізованого опису екологічних впливів на товари та послуги від діяльності підприємств. Більшість соціальних звітів українських компаній містить переважно опис окремих екологічних проектів, без характеристики результатів подібних акцій. Аналіз інформації про наслідки запровадження природоохоронних програм на підприємствах показує, що інформація стосовно зміни обсягів викидів та скидів забруднюючих речовин, структури та кількості полютантів, які потрапляють у довкілля після виконання таких програм, відсутня, а тому екологічна діяльність є скоріше декларативною, ніж дієвою.

Таблиця 2 - Результат діяльності локальних очисних споруд Золотоніського маслоробного комбінату після реконструкції локальних очисних споруд

\begin{tabular}{|c|c|c|}
\hline \multicolumn{2}{|c|}{ Перелік досліджуваних показників } & \multirow{2}{*}{$\begin{array}{l}\text { Нормативний } \\
\text { показник }\end{array}$} \\
\hline від 30.09.2016 & від 15.03.2017 & \\
\hline \multicolumn{3}{|c|}{ Санітарно-хімічні показники } \\
\hline Інтенсивність запаху - 5 балів & Інтенсивність запаху - 2 бали & 1 бал \\
\hline Розчинений кисень -1,1 мг/дм ${ }^{3}$ & Розчинений кисень - 9,6 мг/дм ${ }^{3}$ & Не менше 4 мг/дм ${ }^{3}$ \\
\hline $\begin{array}{l}\text { Хімічне споживання кисню } \\
(\mathrm{XCK})-159,7 \mathrm{MrO}_{2} / \text { дм }^{3}\end{array}$ & $\begin{array}{l}\text { Хімічне споживання кисню (ХСК) - } \\
29,7 \mathrm{MrO}_{2} / \text { дм }^{3}\end{array}$ & $\begin{array}{c}\text { Не більше } \\
30,0 \mathrm{M \Gamma O} / \mathrm{дm}^{3}\end{array}$ \\
\hline Сухий залишок - 1082,0 мг/дм ${ }^{3}$ & Сухий залишок - 469,2 мг/дм ${ }^{3}$ & $\begin{array}{c}\text { Не більше } \\
1000 \text { мг/дм }\end{array}$ \\
\hline Залізо - 1,1 мг/дм ${ }^{3}$ & Залізо - 0,4 мг/дм ${ }^{3}$ & $\begin{array}{l}\text { Не більше } \\
0,3 \text { мг/дм }{ }^{3}\end{array}$ \\
\hline Амоніак - 16,1 мг/дм ${ }^{3}$ & Амоніак - 4,0 мг/дм ${ }^{3}$ & $\begin{array}{l}\text { Не більше } \\
2,0 \text { мг/дм }\end{array}$ \\
\hline \multicolumn{3}{|c|}{ Мікробіологічні показники } \\
\hline $\begin{array}{l}\text { Індекс лактозопозитивної } \\
\text { кишкової палички (ЛКП) - } \\
24000000 \text { в } 1 \text { дм }^{3}\end{array}$ & $\begin{array}{l}\text { Індекс лактозопозитивної кишкової } \\
\text { палички (ЛКП) - } 13000 \text { в } 1 \text { дм }^{3}\end{array}$ & $\begin{array}{l}\text { Не більше } 5000 \\
\text { в } 1 \text { дм }^{3}\end{array}$ \\
\hline $\begin{array}{l}\text { Індекс кишкової палички - } \\
24000000 \text { в } 1 \text { дм }^{3}\end{array}$ & $\begin{array}{l}\text { індекс кишкової палички - } \\
13000 \text { в } 1 \text { дм }^{3}\end{array}$ & $\begin{array}{l}\text { Не більше } 1000 \\
\text { в } 1 \text { дм }^{3}\end{array}$ \\
\hline $\begin{array}{l}\text { Індекс колі-фагів - } 4000 \text { БУО } \\
\text { в } 1 \text { дм }^{3}\end{array}$ & $\begin{array}{l}\text { індекс колі-фагів менший } 100 \text { БУО } \\
\text { в } 1 \text { дм }^{3}\end{array}$ & $\begin{array}{l}\text { Не більше } 100 \\
\text { в } 1 \text { дм }^{3}\end{array}$ \\
\hline $\begin{array}{l}\text { Виявлено бактерії: Сальмонела } \\
\text { ентерітідіс (Salmonella Enteritidis) }\end{array}$ & $\begin{array}{l}\text { Відсутні збудники захворювань та } \\
\text { життєздатні яйця гельмінтів }\end{array}$ & $\begin{array}{c}\text { Відсутність збуд- } \\
\text { ників захворювань } \\
\text { та життєздатних } \\
\text { яєць гельмінтів } \\
\text { в } 1 \text { дм }^{3} \\
\end{array}$ \\
\hline
\end{tabular}

Економічна безпека в умовах економічної стагнації українського бізнесу є для власників пріоритетною в плані стратегічного розвитку підприємства порівняно $з$ екологічними загрозами від його діяльності. Таким чином, дієвість природоохоронних програм та вирішення питань екологічної безпеки на вітчизняних підприємствах, в першу чергу, залежать від свідомості та соціальної відповідальності власників. Це стосується великого бізнесу, який може собі дозволити мільйонні інвестиції в екологічні програми. Для середнього і малого бізнесу, особливо в молочній галузі, актуальним $€$ просто виживання в умо- вах конкурентних загроз глобального світу. Стимулом для запровадження екологічного менеджменту на підприємствах може бути лише необхідність у зв'язку із виходом на світові та європейські ринки.

Висновки. На прикладі Золотоніського маслоробного комбінату розглянуто можливості поліпшення екологічної складової виробництва молокопродуктів та окреслено проблеми, що виникають при технічному переоснащенні основних фондів вітчизняних підприємств. Підприємство 3 2000-х рр. було головним забруднювачем річок Суха Згар і Золотоношка в Черкаській області за раху-

(c) Н. В. Загоруйко, Л. Б. Ящук, Н. І. Свояк, І. С. Конопацька, 2021 DOI: 10.24025/2306-4412.2.2021.229701 
нок скидів значного обсягу недоочищених стічних вод. У період 2015-2017 pp. значні капіталовкладення в переоснащення локальних очисних споруд підприємства, встановлення безвідходних технологічних ліній дали змогу привести стан стічних вод підприємства до нормативних показників і поліпшити ситуацію із забрудненням малих річок. Вирішення проблем в екологічній діяльності на Золотоніському маслоробному комбінаті є прикладом дієвого результативного формування екологічних цілей та стратегії їх досягнення власниками великого молочного холдингу.

Реконструкція наявних локальних очисних споруд на підприємствах потребує значних капіталовкладень, які собі можуть дозволити не всі власники. Оскільки впровадження системи міжнародних екологічних стандартів є добровільним, дорогим і тривалим у часі, то українські виробники не поспішають запроваджувати екологічний менеджмент і сертифікувати свої виробництва відповідно до стандартів ISO 14000. Водночас сертифікація виробництва на ЗМК згідно 3 міжнародним стандартом FSSC 22000:2015, сумісним 3 ISO 9001, ISO 14001, OHSAS 18001, SA8000, ISO 22005 та ISO 22000, покращує перспективи розширення експорту продукції підприємства.

Отже, поліпшення екологічної безпеки молокопереробної галузі України пов'язано 3 інтеграцією в європейський ринок, де діють суворі вимоги до екологічної діяльності виробництв. Саме об'єднання невеликих виробництв у концерн спонукає малі підприємства відповідати вимогам міжнародних стандартів якості й екологічної безпеки. Задля покращення екологічної ситуації регіону підприємствам молочної галузі рекомендується проводити технічне переоснащення та доочищення стічних вод перед подачею на комунальні очисні споруди.

Розроблені заходи екологічного менеджменту на цьому підприємстві можуть бути ефективними для реалізації на вітчизняних підприємствах молочної галузі. Це питання є предметом подальших досліджень.

\section{Список використаних джерел}

[1] О. В. Рибалова. С. В. Анісімова, та О. В. Поддашкін, "Оцінка спрямованості процесів стану екосистем малих річок", Вісник Міжнародного слов'янського університету, т. VI, № 1, с. 12-16, 2003.
[2] В. Д. Романенко, В. М. Жукинський, та О. П. Оксіюк, Методика встановлення $i$ використання екологічних нормативів якості поверхневих вод суші та естуаріїв України. Київ, Україна: Наук. думка, 2001.

[3] О. Г. Власенко, Д. Ю. ВерниченкоЦветков, та О. Ю. Ієвлєва, "Оцінка сучасного екологічного стану басейну Дніпра за гідрохімічними показниками", Проблеми охорони навколишнього природного середовища та екологічної безпеки, вип. 38, с. 43-60, 2016.

[4] О. І. Барановський, А. І. Мокій, та O. I. Дацко, "Економічна безпека підприємницької діяльності в Україні: виклики і загрози", Часопис економічних реформ, вип. 1 (25), с. 17-24, 2017.

[5] В. I. Мунтіян, Економічна безпека Украӥни, Київ, Україна: Вид-во КВІЦ, 1999.

[6] В. Л. Акуленко, та І. В. Мамчук, "Екологічний менеджмент в контексті забезпечення екологічної безпеки підприємства", Вісник Хмельницького національного університету, т. 1, № 5, с. 21-26, 2009.

[7] А. М. Гивлюд, "Моніторинг забруднення стічних вод молокопереробних підприємств", Вісник Національного університеmу "Львівська політехніка". Хімія, технологія речовин та їх застосування, № 787, c. 301-305, 2014

[8] В. А. Андронов, Є. О. Макаров, Ю. М. Данченко, та Т. М. Обіженко, "Дослідження закономірностей формування та хімічного складу стічних вод молокопереробного підприємства", Техногенноекологічна безпека, № 1 (7), с. 13-21, 2020.

[9] Є. О. Макаров. "Екологічна небезпека висококонцентрованих стічних вод молокопереробних підприємств", у матеріалах II Міжнар. симпозіуму SDEV'2020. Сталий розвиток - стан та перспективи, Львів, 2020, с. 235-236.

[10] Cleaner Production Assessment in Dairy Processing: COWI Consulting Engineers and Planners AS, Denmark, 2000. [Online]. Available: https://digitallibrary.un.org.

[11] Стратегіï і практики ресурсоефективного та більш чистого виробництва в молочній промисловості. Київ: Центр ресурсоефективного та чистого виробництва, 2017. [Електронний ресурс]. Режим доступу: http://www.recpc.org/wp-content/uploads/ 2018/02/MolochnaProm_prev.pdf.

[12] Департамент агропромислового розвитку Черкаської ОДА, Довідка про стан справ 
у харчовій та переробній галузі Черкаської області за I півріччя 2020 року, дата публікації 11.08.2020 р. [Електронний ресурс]. Режим доступу: http://apkck.gov.ua/ ?page=post\&id=2336.

[13] Управління екології та природних ресурсів ЧОДА, Висновок з оиінки впливу на довкілля планованої діяльності товариства з додатковою відповідальністю "Золотоніський маслоробний комбінат", [Електронний ресурс]. Режим доступу: http://eia.menr.gov.ua/uploads/documents/ 1887/reports/45491f7dbb09a70941f121bcb1 4bf24c.pdf.

[14] Офіційна сторінка холдингу "Молочний Альянс України". [Електронний ресурс]. Режим доступу: https://milkalliance.com.ua.

[15] С. Корнелюк, "За результатами лабораторних досліджень стан Сухої Згарі та Золотоношки покращується", Новини Чер$\kappa a c, 27$ берез., 2017. [Електронний ресурс]. Режим доступу: https://cherkasy24.info/ 15446-za-rezultatami-laboratornihdosldzhen-stan-suhoyi-zgar-ta-zolotonoshkipokraschuyetsya.html.

\section{References}

[1] O. V. Rybalova, S. V. Anisimova, and O. V. Poddashkin, "Assessment of the direction of the state of small river ecosystems", Visnyk Mizhnarodnoho slovianskoho universytetu, vol. VI, no. 1, pp. 12-16, 2003 [in Ukrainian].

[2] V. D Romanenko, V. M. Zhukynsky, and O. P. Oksiyuk, Methods of establishing and using ecological standards of land surface waters and estuaries of Ukraine. Kyiv, Ukraine: Nauk. dumka, 2001 [in Ukrainian].

[3] A. G. Vasenko, D. U. VernychenkoTsvetkov, and O. Yu. Iievlieva, "The assessment of the current ecological condition of the Dnieper basin by hydrochemical parameters", Problemy okhorony navkolyshnoho pryrodnoho seredovyshcha ta ekolohichnoi bezpeky, iss. 38, pp. 43-60, 2016 [in Ukrainian].

[4] O. I. Baranovsky, A. I. Mokiy, and O. I. Datsko, "Economic security of business in Ukraine: challenges and threats", Chasopys ekonomichnykh reform, iss. 1 (25), pp. 17-24, 2017 [in Ukrainian].

[5] V. I. Muntian, Economic security of Ukraine. Kyiv, Ukraine: Vyd-vo KVITs, 1999 [in Ukrainian].
[6] V. L. Akulenko, and I. V. Mamchuk, "Environmental management in the context of ensuring the environmental safety of the enterprise", Visnyk Khmelnytskoho natsionalnoho universytetu, vol. 1, no. 5, pp. 21-26, 2009 [in Ukrainian].

[7] A. M. Givlyud, "Monitoring of wastewater pollution of milk processing enterprises", Visnyk Natsionalnoho universytetu "Lvivska politekhnika". Khimiia, tekhnolohiia rechovyn ta yikh zastosuvannia, no. 787, pp. 301-305, 2014 [in Ukrainian].

[8] V. A. Andronov, Ye. O. Makarov, Yu. M. Danchenko, and T. M. Obizhenko, "Research of regularities of formation and chemical composition of wastewater of milk processing enterprise", Tekhnohennoekolohichna bezpeka, no. 1 (7), pp. 13-21, 2020 [in Ukrainian].

[9] Ye. O. Makarov, "Ecological danger of highly concentrated sewage of milk processing enterprises", in Proc. II Int. Symposium SDEV'2020. Sustainable Development - Status and Prospects, Lviv, 2020, pp. 235-236 [in Ukrainian].

[10] Cleaner Production Assessment in Dairy Processing: COWI Consulting Engineers and Planners AS, Denmark, 2000. [Online]. Available: https://digitallibrary.un.org.

[11] Strategies and practices for the use of resource-efficient and cleaner production in the dairy industry. Kyiv: Tsentr resursoefektyvnoho ta chystoho vyrobnytstva, 2017. [Online]. Available: http://www.recpc.org/ wp-content/uploads/2018/02/

MolochnaProm_prev.pdf [in Ukrainian].

[12] Department of Agro-Industrial Development of Cherkasy Regional State Administration, Information on the state of affairs in the food and processing industry of Cherkasy region for the first half of 2020, datasheet, Aug. 2020. [Online]. Available: http://apkck.gov.ua/?page=post\&id=2336.

[in Ukrainian].

[13] Department of Ecology and Natural Resources of Cherkasy Regional State Administration, Conclusion on the environmental impact assessment of the planned activities of the additional liability company "Zolotonosha dairy factory", 2018. [Online]. Available: http://eia.menr.gov.ua/ uploads/documents/1887/reports/45491f7dbb 09a70941f121bcb14bf24c.pdf [in Ukrainian].

[14] Official page of the holding "Dairy Alliance of Ukraine". [Online]. Available: 
https://milkalliance.com.ua. Accessed: Jan. 20, 2021 [in Ukrainian].

[15] S. Kornelyuk, "According to the results of laboratory tests, the condition of Sukha Zhar and Zolotonoshka is improving", Novyny
Cherkas, March 27, 2017. [Online]. Available: https://cherkasy24.info/15446-za-rezultatamilaboratornih-dosldzhen-stan-suhoyi-zgar-tazolotonoshki-pokraschuyetsya.html. Accessed: Jan. 5, 2021 [in Ukrainian].

N. V. Zagoruyko, Ph.D., Associate Professor, e-mail: nelli.zagorujko@ukr.net

L. B. Yashchuk, Ph.D., Associate Professor, e-mail: yashchuk@ukr.net

N. I. Svojak, Ph.D., Associate Professor, e-mail: svojaknata@ukr.net

Cherkasy State Technological University

Shevchenko blvd, 460, Cherkasy, 18006, Ukraine

I. S. Konopatska

e-mail: innakonopatcka@gmail.com

Cherkasy Research Forensic Center of the Ministry of Internal Affairs of Ukraine

Pasterivska st., 104, Cherkasy, 18000, Ukraine

\section{ENSURING OF ENVIRONMENTAL SAFETY THROUGH TECHNICAL RE-EQUIPMENT OF ENTERPRISES OF DOMESTIC MILK PROCESSING INDUSTRY}

In Ukraine, dairy production is often carried out on obsolete equipment, due to which environmental pressure of the industry on the environment, especially on water resources, is significant. The wastewater of milk processing industry is intensively polluted with easily soluble organic substances that can cause great damage to water ecosystems. For example, at an average specific water consumption of $5 \mathrm{~m}^{3}$ per ton of milk, depending on the capacity of the enterprise, about $500 \mathrm{~m}^{3}$ of wastewater is generated per day.

Zolotonosha dairy factory is the flagship of the economy of the city of Zolotonosha and at the same time in 2000-2012 was the main polluter of the local small rivers Sukha Zgar and Zolotonoshka due to discharges of a significant amount of untreated wastewater. In 2006, the factory became a part of a large holding "Dairy Alliance of Ukraine", among the many goals of which is the reduction of environmental pressure of dairy factories on the environment. In 2015-2017, the management of the holding made significant investments in the reconstruction of local treatment facilities of the enterprise and the installation of waste-free technological lines. This made it possible to bring the condition of wastewater to regulatory standards and improve the situation with pollution of small rivers.

Solving problems in environmental activities at Zolotonosha dairy factory is an example of the possibility of ensuring the safety of water ecosystems through the implementation of environmental management at the enterprise. Today in Ukraine significant investments in reconstruction and ecological modernization of enterprises are available only to large companies. Certification of production at the investigated factory according to the international standard FSSC 22000:2015 improves the prospects for expanding exports of the company's products. Improvement of environmental safety of the Ukrainian milk processing industry is associated with further integration into the European market, where under the pressure of strict requirements of the European legislation to environmental consequences, Ukrainian manufacturers are forced to implement environmental management.

Keywords: wastewater, surface water quality, standard, trademark, ecological standards, waste-free technologies.

Стаття надійшла 21.04.2021

Прийнято 16.06.2021

(c) Н. В. Загоруйко, Л. Б. Ящук, Н. І. Свояк, І. С. Конопацька, 2021

DOI: 10.24025/2306-4412.2.2021.229701 